https:// doi.org/10.15407/mineraljournal.43.01.003

UDC 549.61 (477)

D.K. Voznyak, DrSc (Geology), Chief Research Fellow

M.P. Semenenko Institute of Geochemistry, Mineralogy and Ore Formation of the NAS of Ukraine

34, Acad. Palladin Ave., Kyiv, Ukraine, 03142

E-mail: dkvoznyak@ukr.net; https://orcid.org/0000-0002-6124-2033

E.V. Levashova, PhD (Geology \& Mineralogy), Junior Research Fellow

Institute of Precambrian Geology and Geochronology of RAS

2, Makarova Emb., St. Petersburg, Russia, 199034

E-mail: levashova.kateryna@yandex.ru; https:/ / orcid.org/0000-0002-0814-1428

S.G. Skublov, DrSc (Geology \& Mineralogy), Prof., Chief Research Fellow

Institute of Precambrian Geology and Geochronology of RAS

2, Makarova Emb., St. Petersburg, Russia, 199034

Saint Petersburg Mining University

2, 21st Line, St. Petersburg, Russia, 199106

E-mail: skublov@yandex.ru; http:/ / orcid.org/0000-0002-5227-4260

S.G. Kryvdik, DrSc (Geology \& Mineralogy), Prof., Senior Research Fellow

M.P. Semenenko Institute of Geochemistry, Mineralogy and Ore Formation of the NAS of Ukraine 34, Acad. Palladin Ave., Kyiv, Ukraine, 03142

E-mail: kryvdik@ukr.net; https://orcid.org/0000-0002-8356-1115

O.A. Vyshnevskyi, PhD (Geology \& Mineralogy), Senior Research Fellow

M.P. Semenenko Institute of Geochemistry, Mineralogy and Ore Formation of the NAS of Ukraine

34, Acad. Palladin Ave., Kyiv, Ukraine, 03142

E-mail: vyshnevskyy@i.ua; ResearcherID: I-9996-2018

V.M. Belskyi, PhD (Geology), Research Fellow

M.P. Semenenko Institute of Geochemistry, Mineralogy and Ore Formation of the NAS of Ukraine 34, Acad. Palladin Ave., Kyiv, Ukraine, 03142

E-mail: belskyi_vm@ukr.net; ResearcherID: K-8607-2018

S.I. Kurylo, PhD (Geology), Research Fellow

Earth Science Institute Slovak Academy of Sciences

974 01, Banska Bystrica, Slovakia, Dumbierska, 1

E-mail: kurylo.sergiy@gmail.com; https:/ / orcid.org/0000-0003-4466-6851

\title{
FORMATION MECHANISM OF THE VELYKA VYSKA SYENITE MASSIF (KORSUN-NOVOMYRHOROD PLUTON, UKRAINIAN SHIELD) DERIVED FROM MELT INCLUSIONS IN ZIRCON
}

The formation of leucosyenites in the Velyka Vyska syenite massif was provoked by the liquation layering of magmatic melt. This assumption is based on the presence of two primary melt inclusions of different chemical composition in zircon crystals from Velyka Vyska leucosyenites. They correspond to two types of silicate melts. Type I is a leucosyenite type that contains high $\mathrm{SiO}_{2}$ concentrations (these inclusions dominate quantitatively); type II is a melanosyenite type that contains elevated $\mathrm{FeO}$ and smaller $\mathrm{SiO}_{2}$ concentrations. The liquation

Cite: Voznyak, D.K., Levashova, E.V., Skublov, S.G., Kryvdik, S.G., Vyshnevskyi, O.A., Belskyi, V.M., Kurylo, S.I. (2021), Formation Mechanism of the Velyka Vyska Syenite Massif (Korsun-Novomyrhorod Pluton, Ukrainian Shield) Derived from Melt Inclusions in Zircon. Mineral. Journ. (Ukraine), 43, No. 1, pp. 3-15. https://doi.org/10.15407/mineraljournal.43.01.003 
layering of magmatic melt was slow because the liquates are similar in density; leucosyenite melt, which is more abundant than melt of melanosyenite composition, displays greater dynamic viscosity; the initial sizes of embryos of melanosyenite composition are microscopic. Sulphide melt, similar in composition to pyrrhotite, was also involved in the formation of the massif. Zircon was crystallized at temperatures over $1300^{\circ} \mathrm{C}$, as indicated by the homogenization temperatures of primary melt inclusions. The REE distribution spectra of the main parts (or zones,) of zircon crystals from the Velyka Vyska massif are identical to those of zircon from the Azov and Yastrubets syenite massifs with which high-grade Zr and REE (Azov and Yastrubets) ore deposits are associated. They are characteristic of magmatically generated zircon. Some of the grains analyzed contain rims that are contrasting against the matrix of a crystal, look dark-grey in the BSE image and display flattened REE distribution spectra. Such spectra are also typical of baddeleyite, which formed by the partial replacement of zircon crystals. The formation of a dark-grey rim in zircon and baddeleyite is attributed to the strong effect of high-pressure $\mathrm{CO}_{2}$-fluid on the rock. The formation patterns of the Velyka Vyska and Azov massif exhibit some common features: (a) silicate melt liquation; (b) high $\mathrm{ZrO}_{2}$ concentrations in glasses from hardened primary melt inclusions; (c) the supply of high-pressure $\mathrm{CO}_{2}$-fluid flows into Velyka Vyska and Azov hard rocks. Similar conditions of formation suggest the occurrence of high-grade $\mathrm{Zr}$ and REE ores in the Velyka Vyska syenite massif.

Keywords: syenite, melt inclusions, zircon, REE, Velyka Vyska massif, Ukrainian Shield.

Introduction. The Velyka Vyska syenite massif comprises several elongated bodies. The biggest body is $4.5 \times 2 \mathrm{~km}$ in size. Syenites occur among rapakivi granites, less common among the porphyry granites of the Novoukrainian massif or near the contact of these rocks on the south margin of the KorsunNovomyrhorod pluton (Ingul megablock of the Ukrainian Shield [14, 15]. The contact of Velyka Vyska quartz-bearing fayalitic-hedenbergitic syenites with granites is sharp and intrusive. The elevated granularity in the endocontact zone is due to hardening.

Occurring on the Ukrainian Shield are four nepheline-free syenite massifs: the Velyka Vyska massif, the Yastrubets massif, the East Priazov complex and Davidkivsky massif. They contain elevated to high zirconium, lanthanide and yttrium concentrations $[15,11]$. The massifs are of Proterozoic age (ca. $1.8 \mathrm{Ga}$ ). They display distinctive Ukrainian Shield alkaline magmatism. The syenites are spatially and genetically related to anorthosite-rapakivi granite plutons and display a syenite evolution trend [11, 12, 15]. They have been described earlier under various names: gabbro-syenite formation (a term suitable for most of the alkaline rock massifs in the Ukrainian Shield [15], anorthosite-rapakivi granite complexes, rare-metal syenites [13] and hypersolvus syenites [21-24]. Associated with these rare-metal nepheline-free syenites are the non-conventional Azov and Yastrubets high-grade deposits dominated by zircon, britholite and orthite (allanite) [1, 11].

Syenites derived from subalkaline basalts were enriched in $\mathrm{Zr}$ and $R E E$ at the final stages of gab- bro-syenite rocks formation in the Ukrainian Shield. They formed under reducing conditions after the Fenner or similar trend with the precipitation of zircon, britholite and allanite crystals and the formation of high-grade $\mathrm{Zr}$ and $R E E$ ores [11, 14]. Hypersolvus (monofeldspathic) syenites are assumed $[7,24]$ to have been derived from earlier subsolvus (bifeldspathic) syenites.

In the Azov massif, subsolvus syenites host hypersolvus syenites which are exclusively ore-bearing [24]. In the Yastrubets massif, ore-free endocontact syenites contain plagioclase, for example they are subsolvus, while in the central portion of the massif all syenites (in particular, ore-bearing syenites) are hypersolvus. Plagioclase-bearing (10$15 \%$ ) varieties often occur in the Velyka Vyska massif, while plagioclase-enriched $(25-35 \%)$ syenite varieties are less common [14].

Dark-coloured minerals in the syenites of the gabbro-syenite formation are rich in iron [15]. Fayalite, hedenbergite and ferrohastingsite from Velyka Vyska syenites are also rich in iron (up to $100 \%$ of Fe end-members) [14]. Contrasting rock types display the following dark-coloured mineral distribution: ferrohastingsite occurs in melanocratic syenites, while annite commonly occurs in leucosyenites $[23,24]$. Velyka Vyska syenites are similar to rocks from the South Kalchik massif, but are more similar in some features to Azov syenites [11]. Velyka Vyska syenites were found to contain more $\mathrm{Zr}$, $R E E, \mathrm{Y}$ and $\mathrm{Nb}$ than South Kalchik syenites [11]. No economically significant areas of zircon or other rare-metal minerals ores in Velyka Vyska syenites have been found.

ISSN 2519-2396. Mineral. Journ. (Ukraine). 2021. 43, No. 1 
Melt inclusions have cast light on the formation mechanism of the Azov and Yastrubets deposits. Melt inclusions were analyzed to reconstruct the conditions of formation of the Velyka Vyska syenite massif [16]. Lack of detailed studies of melt inclusions in zircon crystals from the Velyka Vyska massif provided an impetus to this study.

Goals of the study. 1. To reconstruct the conditions of formation of Velyka Vyska leucosyenite from the results of the study of: (a) primary melt inclusions in zircon crystals; (b) the chemical and trase-element composition of zircon; (c) the conditions of formation of baddeleyite upon partial zircon replacement. 2. To evaluate the deposit's ore potential.

Samples and research methods. Zircon crystals from Velyka Vyska leucosyenite from V.I. Orsa's collection were analyzed [14].

The temperatures of phase transitions in melt inclusions were measured by hardening on equipment with a cilite heating device [2] because the inclusions were small. Zircon crystallization temperature was also estimated with a "Ti-in zircon" thermometer [40].

Analytical techniques. The chemical composition and internal structure of zircon and melt inclusions were studied using: 1) a field emission scanning electron microscope JSM-6700F equipped with an energy-dispersive spectrometer (EDS) JED-2300 at M.P. Semenenko Institute of Geochemistry, Mineralogy and Ore Formation (IGMOF) of the NAS of Ukraine (Kyiv). Back-scattered electrons (BSE) images and quantitative EMPA were obtained on carbon-coated samples at operating conditions of $20 \mathrm{kV}$ accelerating voltage, $0.75 \mathrm{nA}$ beam current, $1 \mu \mathrm{m}$ beam size and a counting time of 60 seconds for one analysis. Pure $\mathrm{Si}, \mathrm{Ti}$, $\mathrm{Zr}, \mathrm{Al}, \mathrm{Fe}, \mathrm{Mn}$ and synthetic $\mathrm{MgO}, \mathrm{CaF}_{2}, \mathrm{Na}_{3} \mathrm{AlF}_{6}$, $\mathrm{KCl}$ were used for calibration. Raw counts were corrected for matrix effects with the ZAF algorithm implemented by JEOL; 2) a JXA-8530F field emission microprobe equipped with five wavelengthdispersive spectrometers (WDS) at the Earth Science Institute Slovak Academy of Sciences (Banska Bystrica). Operating conditions were as follows: accelerating voltage of $15 \mathrm{kV}$, beam current of $20 \mathrm{nA}$, beam diameter of 3-5 $\mu \mathrm{m}$. Depending on the element analyzed peak counting times were 10$20 \mathrm{~s}$ and counting times for background 5-10 s on each side of the peak. Raw counts were corrected using a ZAF routine; 3) a JSM-6510LV electron microscope equipped with EDS JED-2200 at Institute of Precambrian Geology and Geochrono- logy (IPGG) of RAS (St. Petersburg). The following operating conditions were used: $20 \mathrm{kV}$ accelerating voltage, $20 \mathrm{nA}$ beam current, and a beam diameter of $3 \mu \mathrm{m}$; 4 ) a Cameca IMS-4f ion microprobe at Valiev IPT of RAS (Yaroslavl branch). To quantify the $R E E$ concentrations of zircon the standard SIMS procedures [30, 33] were employed.

Terminology. The authors used: (a) the terms and binary genetic classification of fluid inclusions proposed by G.G. Lämmlein [20] and V.A. Kalyuzhny [8, 9]; (b) a genetic classification of hard inclusions proposed by V.A. Mokievskyi and Yang Feng-Chun [25] with one addition: in the genetic classification of hard inclusions the terms "protogenetic-syngenetic-epigenetic" [3] are preferred to their synonyms (correspondingly primary, simultaneous and secondary).

Results. 34 zircon crystals from Velyka Vyska leucosyenite were analyzed. Most of the crystals are $0.2-0.4 \mathrm{~mm}$ in size along with $\mathrm{L}_{4}$. Transparent light brown-yellow crystals have perfect crystallographic facets. Alternation of zones with various shades of colour in the BSE image was observed on a crystal with optically contrasting growth pyramids. There is a darker rim on the edge of some of the zircon crystals. It has a contrasting contact with the light-grey central portion of the mineral. Two zircon crystals have a rim consisting of drop-like baddeleyite individuals pressed firmly against each other. The crystals contain an abundance of primary melt inclusions.

Habit and anatomy of zircon crystals. The dipyramidal-prismatic habit of the crystals is based on such simple shapes as: a tetragonal prism $\{110\}$ and a tetragonal dipyramid $\{111\}$; other shapes are less common $\{331\},\{311\},\{100\}$. Many of the crystals display a finely zonal structure with distinct facet growth pyramids of the shapes $\{110\}$ and $\{111\}$ [16]. Zircon crystals from the Yastrubets [15] and Azov deposits are structurally similar [10]. The volumes of growth pyramids $<111>$ in most individuals are greater than those of $\langle 110\rangle$, although an inverse relationship is observed for facet area $(\{110\}>$ $>\{111\})$. Sometimes the volume of the growth pyramids $\langle 110\rangle$ makes up $10 \%$ of crystal volume. In zircon strongly dominated by the growth pyramid $<111>$ crystal embryos are commonly faceted by the dipyramid $\{111\}$ and in other cases by $\{110\}+\{111\}$. The zircon in the pyramid $<111>-$ is light-grey, while that in $\langle 110\rangle$ is colourless.

Only the shapes $\{111\}$ and $\{110\}$ of zircon crystals are most important structurally. Their facets have their growth pyramids, which are overgrown 


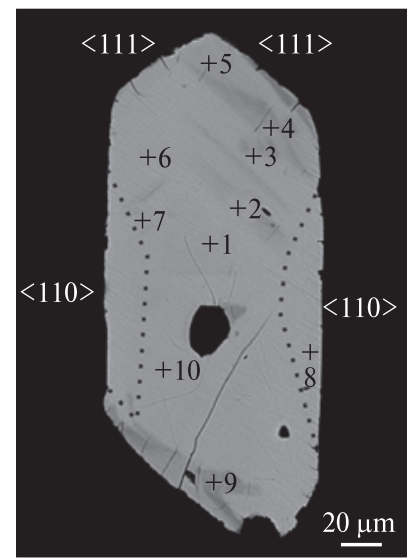

Fig. 1. Sectorial structure (image in a BSE mode) of a zircon crystal from Velyka Vyska leucosyenites. A dashed line delineates the growth pyramid $<110>$. JXA-8530F microanalyzer

by layers and have a smooth, flat surface. Under perfect growth conditions, zircon crystals are expected to be formed only by facets of two shapes $\{111\}$ and $\{110\}$.

Mineral inclusions in a zircon crystals. Zircons from leucosyenites were found to contain apatite inclusions which dominate quantitatively in crystals (sometimes quartz in two cases baddeleyite) and the mineral phases of melt inclusions. Albite, K-feldspar, allanite-(Ce), monazite-(Ce) (?), fluorbritholite-(Ce) (?), parisite-(Ce) (?), bastnaesite(Ce) (?), epidote, fluorapatite, calcite, chalcopyrite and other phases were also revealed in zircon crystals from the Velyka Vyska syenite massif by electron probe analysis [17, 35].

Apatite. Protogenetic apatite inclusions in zircon from Velyka Vyska leucosyenite occur as transparent elongated hexahedral prisms and acicular crystals measuring $10-15$ to $100-150 \mu \mathrm{m}$ lengthwise. Syngenetic inclusions, occurring as isometric individuals measuring 40-50 $\mu \mathrm{m}$, are occasionally encountered. Melt inclusions often "stick" to acicular crystals. In addition to major constituents, apatite (3 inclusions, 8 points) contains (wt.\%): F (2.14.15); $\mathrm{SiO}_{2}$ (0.98-4.07); $\mathrm{Ce}_{2} \mathrm{O}_{3}(0.57-1.83)$ and in one case $\mathrm{Nd}_{2} \mathrm{O}_{3}$ (2.35). Sometimes inclusions are heterogeneous in composition, for example zones without $\mathrm{F}$ and $\mathrm{Ce}_{2} \mathrm{O}_{3}$ are encountered.

Quartz (tridymite?). Protogenetic inclusions, measuring $40 \times 20 \mu \mathrm{m}$ in the polished off-cut plane have linear restrictions and a shape similar to a rectangle. The mineral contains only $\mathrm{SiO}_{2}$ (JSM $6700 \mathrm{~F}$ electron microscope). As the crystallization temperature of zircon is over $1300{ }^{\circ} \mathrm{C}$, the inclusions revealed consist of quartz and possibly tridymite.

Baddeleyite. Tiny drop-like mineral aggregates in the glass were found on: (a) the prism facet of a zircon crystal and on the cavity surface of a melt inclusion and (b) the facet of a tetragonal dipyramid. Some of the baddeleyite individuals are 15$25 \mu \mathrm{m}$ in size. The mineral contains $1-2 \mathrm{wt} . \% \mathrm{HfO}_{2}$. The formation mechanism of baddeleyite, which partly replaces zircon crystals, is essential for the reconstruction of the conditions of formation of the Velyka Vyska massif, because similar aggregates on the Azov deposit formed when high-pressure $\mathrm{CO}_{2}$-fluid flows affected the rock.

Chemical composition of zircon. The chemical composition of a sectorial-structured crystal, in which the growth pyramids $\langle 111\rangle$ and $\langle 110\rangle$ are well-defined optically, is shown in Table 1 . The growth layers in the growth pyramid $<111>$ are commonly about $1 \mu \mathrm{m}$ thick, sometimes $5-10 \mu \mathrm{m}$. In the BSE image, the sectorial crystal structure (Fig. 1) is much less distinct. Calculations show that $\mathrm{ZrO}_{2}, \mathrm{SiO}_{2}$ and $\mathrm{HfO}_{2}$ contribute mostly to the mean value of zircon's atomic mass. As the contri-

Table 1. Chemical composition (wt.\%) of a zircon crystal with optically distinct growth pyramids $<111>$ and $<110>$ (Fig. 1) in Velyka Vyska leucosyenite

\begin{tabular}{|c|c|c|c|c|c|c|c|c|c|}
\hline \# in order & $\mathrm{SiO}_{2}$ & $\mathrm{ZrO}_{2}$ & $\mathrm{HfO}_{2}$ & $\mathrm{Y}_{2} \mathrm{O}_{3}$ & $\mathrm{~Tb}_{2} \mathrm{O}_{3}$ & $\mathrm{Yb}_{2} \mathrm{O}_{3}$ & $\mathrm{MnO}$ & $\mathrm{FeO}$ & $\mathrm{Sum} *$ \\
\hline 1 & 32.40 & 63.54 & 1.75 & 0.13 & 0.19 & 0.07 & 0 & 0.13 & 98.21 \\
2 & 32.25 & 63.88 & 1.71 & 0.21 & 0.02 & 0.09 & 0.10 & 0.07 & 98.33 \\
3 & 32.43 & 63.72 & 1.79 & 0.02 & 0.10 & 0.08 & 0.04 & 0 & 98.18 \\
4 & 32.11 & 63.46 & 1.72 & 0.11 & 0.23 & 0.05 & 0.06 & 0.09 & 97.83 \\
5 & 32.82 & 63.94 & 1.72 & 0.20 & 0.14 & 0.05 & 0 & 0.10 & 98.97 \\
6 & 31.91 & 63.78 & 1.76 & 0.08 & 0.15 & 0.08 & 0.10 & 0.01 & 97.87 \\
7 & 32.63 & 64.11 & 1.72 & 0.12 & 0.17 & 0.19 & 0.02 & 0 & 98.96 \\
8 & 32.64 & 64.12 & 1.71 & 0.36 & 0.07 & 0.13 & 0.02 & 0 & 99.05 \\
9 & 32.67 & 64.21 & 1.83 & 0.03 & 0.14 & 0.04 & 0.13 & 0.03 & 99.08 \\
10 & 32.79 & 64.06 & 1.71 & 0.33 & 0.15 & 0 & 0 & 0 & 99.04 \\
\hline
\end{tabular}

* Without account of: $\mathrm{K}_{2} \mathrm{O}, \mathrm{Na}_{2} \mathrm{O}, \mathrm{CaO}, \mathrm{MgO}, \mathrm{SrO}, \mathrm{PbO}, \mathrm{Al}_{2} \mathrm{O}_{3}, \mathrm{P}_{2} \mathrm{O}_{5}, \mathrm{TiO}_{2}, \mathrm{ThO}_{2}, \mathrm{UO}_{2}, \mathrm{Sm}_{2} \mathrm{O}_{3}, \mathrm{Eu}_{2} \mathrm{O}_{3}, \mathrm{Dy}_{2} \mathrm{O}_{3}, \mathrm{Ho}_{2} \mathrm{O}_{3}$, $\mathrm{Tm}_{2} \mathrm{O}_{3}, \mathrm{Lu}_{2} \mathrm{O}_{3}$. Microprobe analyzer JXA-8530F. 

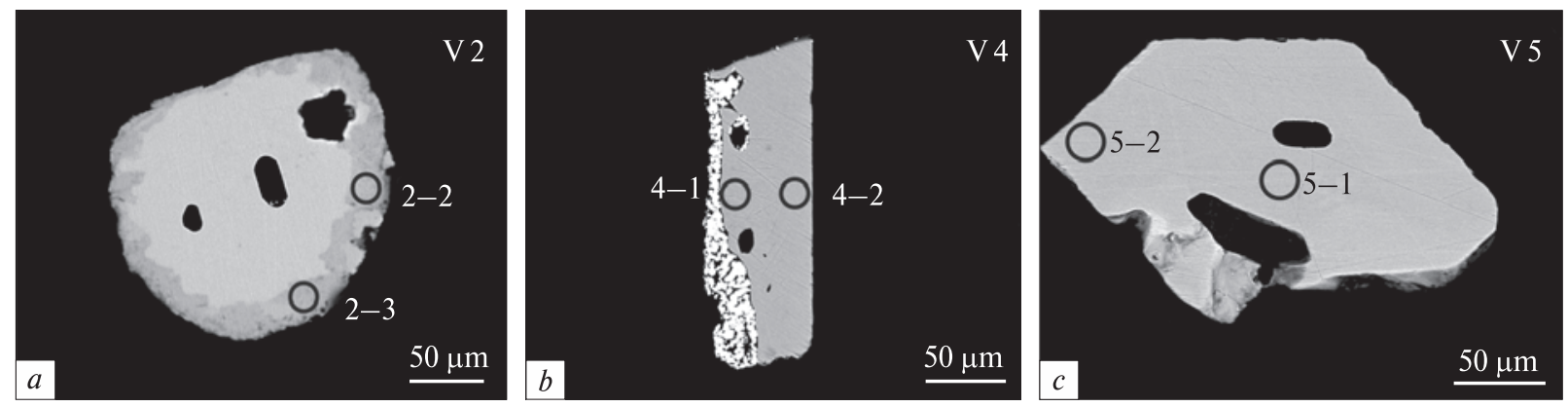

Fig. 2. Image (in the $B S E$ mode) of zircon crystals with the mineral points analyzed by the SIMS method. The ion probe crater is $\approx 20 \mu \mathrm{m}$ in diameter. Point numbers are consistent with those in Table 2

bution of $\mathrm{SiO}_{2}$ to the mean atomic mass of zircon is nearly identical, the zoning of a crystal is controlled by zirconium and hafnium concentrations in the mineral. The mean atomic mass of grey crystal zones is slightly smaller than that of light zones, as indicated by mean values.

$\mathrm{HfO}_{2}$ concentration in zircon from 12 other crystals (26 analyses) varies from 1.21 to $2.05 \mathrm{wt} . \%$. The $\mathrm{ZrO}_{2} / \mathrm{HfO}_{2}$ ratio varies much greater than in the crystal with optically distinct zoning (from 33.16 to 52.91, mean value 34.40). Thus, the $\mathrm{ZrO}_{2} /$ $\mathrm{HfO}_{2}$ ratio in crystals from Velyka Vyska leucosyenite varies over a broad range. The distribution of other elements in light zircon in the BSE image is also unstable, and their concentrations are usually extremely small. $\mathrm{Y}_{2} \mathrm{O}_{3}$ (up to 0.37 ), $\mathrm{Tb}_{2} \mathrm{O}_{3}$ (up to 0.36 ), $\mathrm{Gd}_{2} \mathrm{O}_{3}$ (up to 0.18 ), $\mathrm{FeO}$ (up to 0.13 ) concentrations (wt.\%) are valid.

Trace-element composition of zircon. Trace and rare-earth element concentrations were estimated using the SIMS method at 6 points of 3 zircon crystals (Fig. 2). Zircon crystals studied displays two types of REE distribution spectra. Type I is characteristic of central and marginal crystal zones of light-grey zircon crystals in the BSE image (V4.1, V4.2, V.5.1, V5.2, Table 2). They exhibit a differentiated light to heavy $R E E$ distribution spectrum $\left(\mathrm{Lu}_{\mathrm{N}} / \mathrm{La}_{\mathrm{N}}\right.$, mean value 2154$)$ with a well-defined positive Ce-anomaly $(\mathrm{Ce} / \mathrm{Ce}$ * varies from 5.55 to 16.4, averaging 12.24) and a negative Eu-anomaly $\left(\mathrm{Eu} / \mathrm{Eu}^{*} 0.07\right.$ to 0.08$)$ and a relatively small total $R E E$ concentration (395-899 ppm) controlled by HREE's contribution (Fig. 3). The spectra determined are similar to those characteristics of the main type of zircon from the Velyka Vyska Massif [35] and are consistent of the typical zircon of magmatic genesis (Fig. 3) [31, 34].

Spectra of type II obtained from a dark rim, which is seen around a zircon V2 crystal in the BSE image (Fig. 2) (analyses V2.2 and V2.3, Table 2).

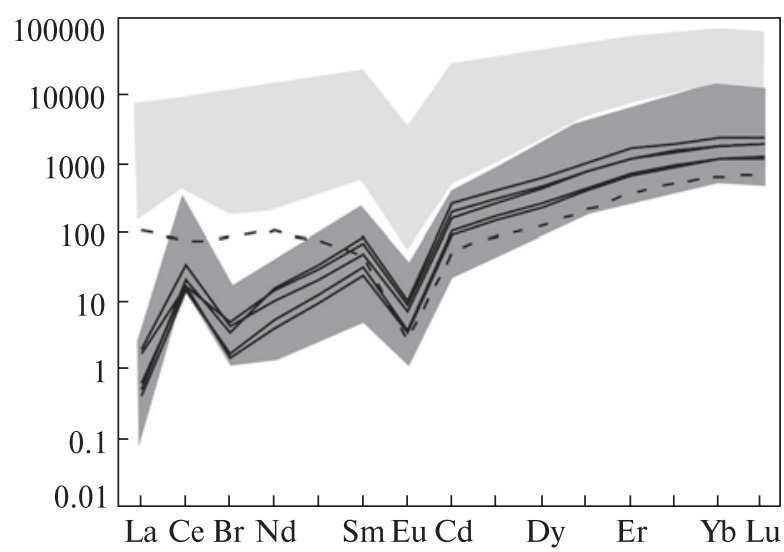

Fig. 3. Chondrite Cl-normalized REE distribution spectra in zircon [37]: the solid line is for unaltered central and marginal zones of zircon from Velyka Vyska leucosyenites; the dashed line is for the altered rims of zircon from Velyka Vyska leucosyenite); dark grey filling is for unaltered zircon from Azov and Yastrubets syenites; light grey filling is for the altered rims of zircon from Azov and Yastrubets syenites

REE distribution in it shows a gently dipping pattern with a reduced Ce-anomaly forming a "bird's wings" spectrum (Fig. 3): REE composition in zircon becomes "lighter". Such a type of spectrum is typical of rocks strongly affected by fluids [28].

In the BSE image, the contact between the dark and light varieties of zircon generally imitates the external shape of a grain (Fig. 2,a). The distinctive pattern of the contact is due to the recrystallization of the zircon edge strongly affected by high-pressure $\mathrm{CO}_{2}$-fluid upon the formation of the Azov and Velyka Vyska syenite massifs. For the former massif it is supported by the presence of corresponding fluid inclusions [39] and for the latter by assumed fluid flows.

$R E E$ distribution in baddeleyite formed upon zircon recrystallization V4 (Fig. 4) largely inherits $R E E$ distribution in zircon: positive $\mathrm{Ce}$ - and nega- 
tive Eu-anomalies are observed, HREE concentration is similar and only LREE concentration in baddeleyite increases more substantially than in zircon. For example, as $L R E E$ concentration is 10$20 \mathrm{ppm}$ in zircon and 750-900 ppm in baddeleyite, the $R E E$ spectrum is flattened (Fig. 4). Furthermore, baddeleyite contains elevated $\mathrm{Sr}$ (300-400 ppm) and $\mathrm{Ti}(360-890 \mathrm{ppm})$ concentrations, but Th and $\mathrm{U}$ concentrations are low. REE spectra in baddeleyite and zircon in the darker edge of grain V2 (Fig. 3 and 4) are identical.
Melt inclusions. Zircon is one of the earliest minerals in the Velyka Vyska syenite massif. Genetic information obtained for primary melt inclusions illustrates an early stage in the formation of the massif. Primary melt inclusions dominate in crystals. They are small in size (10-15 - 20-25 $\mu \mathrm{m}$, sometimes bigger). Their shape is negative crystals, occasionally irregular, and they have an elongated, short-columnar, isometric habit. Secondary inclusions heal fractures in zircon crystals and are scarce.

Table 2. Composition and concentrations of trace elements (ppm) in zircon and baddeleyite from Velyka Vyska leucosyenite. Analytical numbers are consistent with those on the crystals (Fig. 2 and 4)

\begin{tabular}{|c|c|c|c|c|c|c|c|c|c|}
\hline \multirow{2}{*}{ Components } & $\mathrm{V} 2.2$ & V2.3 & V4.1 & V4.2 & V5.1 & V5.2 & V4.3 & V4.4 & $\mathrm{V} 4.5$ \\
\hline & \multicolumn{2}{|c|}{ Dark edge } & \multicolumn{4}{|c|}{ Light edge } & \multicolumn{3}{|c|}{ Baddeleyite } \\
\hline $\mathrm{La}$ & 0.10 & 24.9 & 0.14 & 0.12 & 0.40 & 0.46 & 69.3 & 48.1 & 45.1 \\
\hline $\mathrm{Ce}$ & 8.41 & 42.2 & 9.45 & 12.0 & 9.62 & 19.9 & 713 & 621 & 771 \\
\hline $\operatorname{Pr}$ & 0.16 & 7.73 & 0.14 & 0.31 & 0.44 & 0.38 & 20.7 & 14.5 & 13.7 \\
\hline $\mathrm{Nd}$ & 2.43 & 46.0 & 1.73 & 6.57 & 6.17 & 4.48 & 79.6 & 60.7 & 55.9 \\
\hline $\mathrm{Sm}$ & 4.40 & 6.52 & 3.39 & 12.4 & 9.92 & 7.04 & 26.8 & 21.1 & 20.3 \\
\hline $\mathrm{Eu}$ & 0.21 & 0.15 & 0.19 & 0.54 & 0.48 & 0.39 & 3.75 & 2.19 & 3.06 \\
\hline $\mathrm{Gd}$ & 19.5 & 10.5 & 17.0 & 51.3 & 39.0 & 31.6 & 57.6 & 50.5 & 46.0 \\
\hline Dy & 62.5 & 29.1 & 55.7 & 150 & 111 & 104 & 143 & 125 & 121 \\
\hline $\mathrm{Er}$ & 110 & 55.9 & 105 & 252 & 185 & 182 & 236 & 214 & 204 \\
\hline $\mathrm{Yb}$ & 180 & 101 & 175 & 357 & 282 & 276 & 168 & 154 & 163 \\
\hline $\mathrm{Lu}$ & 29.5 & 15.7 & 27.4 & 56.9 & 45.5 & 44.8 & 53.7 & 49.6 & 48.3 \\
\hline $\mathrm{Li}$ & 1.56 & 1.12 & 0.25 & 0.32 & 1.45 & 1.18 & 0.81 & 0.68 & 3.83 \\
\hline $\mathrm{P}$ & 43.7 & 373 & 96.4 & 59.3 & 84.4 & 81.7 & N. d. & N. d. & N. d. \\
\hline $\mathrm{Ca}$ & 82.1 & 1005 & 44.2 & 63.1 & 255 & 106 & 220 & 163 & 176 \\
\hline $\mathrm{Ti}$ & 19.4 & 18.9 & 20.8 & 13.2 & 126 & 19.0 & 549 & 362 & 885 \\
\hline $\mathrm{Sr}$ & 1.66 & 2.91 & 0.97 & 0.82 & 3.55 & 2.08 & 400 & 290 & 317 \\
\hline Y & 599 & 287 & 577 & 1382 & 974 & 964 & 1307 & 1120 & 1117 \\
\hline $\mathrm{Nb}$ & 34.0 & 44.8 & 33.5 & 27.2 & 26.6 & 25.9 & N. d. & N. d. & N. d. \\
\hline $\mathrm{Ba}$ & 1.88 & 13.8 & 2.56 & 2.39 & 2.94 & 1.83 & N. d. & N. d. & N. d. \\
\hline $\mathrm{Hf}$ & 10082 & 10606 & 11449 & 11458 & 9960 & 12836 & 10116 & 10567 & 9639 \\
\hline $\mathrm{Th}$ & 59.3 & 38.5 & 60.4 & 119 & 93.4 & 144 & 102 & 94.4 & 66.9 \\
\hline $\mathrm{U}$ & 107 & 129 & 119 & 171 & 158 & 272 & 100 & 102 & 62.2 \\
\hline $\mathrm{Th} / \mathrm{U}$ & 0.56 & 0.30 & 0.51 & 0.70 & 0.59 & 0.53 & 1.02 & 0.93 & 1.08 \\
\hline $\mathrm{Eu} / \mathrm{Eu}^{*}$ & 0.07 & 0.05 & 0.08 & 0.07 & 0.07 & 0.08 & 0.29 & 0.20 & 0.31 \\
\hline $\mathrm{Ce} / \mathrm{Ce}^{*}$ & 16.5 & 0.73 & 16.4 & 15.4 & 5.55 & 11.6 & 4.56 & 5.68 & 7.51 \\
\hline$\Sigma R E E$ & 417 & 339 & 395 & 899 & 690 & 671 & 1571 & 1361 & 1493 \\
\hline$\Sigma L R E E$ & 11.1 & 121 & 11.5 & 19.0 & 16.6 & 25.2 & 883 & 744 & 886 \\
\hline$\Sigma H R E E$ & 401 & 212 & 380 & 867 & 663 & 638 & 658 & 594 & 583 \\
\hline $\mathrm{Lu}_{N} / \mathrm{La}_{N}$ & 2962 & 6.08 & 1844 & 4737 & 1099 & 936 & 7.46 & 9.93 & 10.3 \\
\hline $\mathrm{Lu}_{N} / \mathrm{Gd}_{N}$ & 12.3 & 12.2 & 13.1 & 8.97 & 9.45 & 11.5 & 7.53 & 7.94 & 8.49 \\
\hline $\mathrm{Sm}_{N} / \mathrm{La}_{N}$ & 73.4 & 0.42 & 37.9 & 171 & 39.8 & 24.4 & 0.62 & 0.70 & 0.72 \\
\hline$T \mathrm{Ti}-\mathrm{Zrn},{ }^{\circ} \mathrm{C}$ & 805 & 802 & 812 & 768 & 1029 & 803 & N. d. & N. d. & N. d. \\
\hline
\end{tabular}

N o t e. Microprobe analyzer: Cameca IMS-4f; N. d. - no analysis done. 
Fig. 4. Image (in the BSE mode) of zircon (grain V4) partly replaced by baddeleyite from Velyka Vyska leucosyenites and $\mathrm{Cl}$ chondrite-normalized REE distribution spectra [37] in zircon (V4.1, V4.2) and baddeleyite (V4.3, V4.4, V4.5)
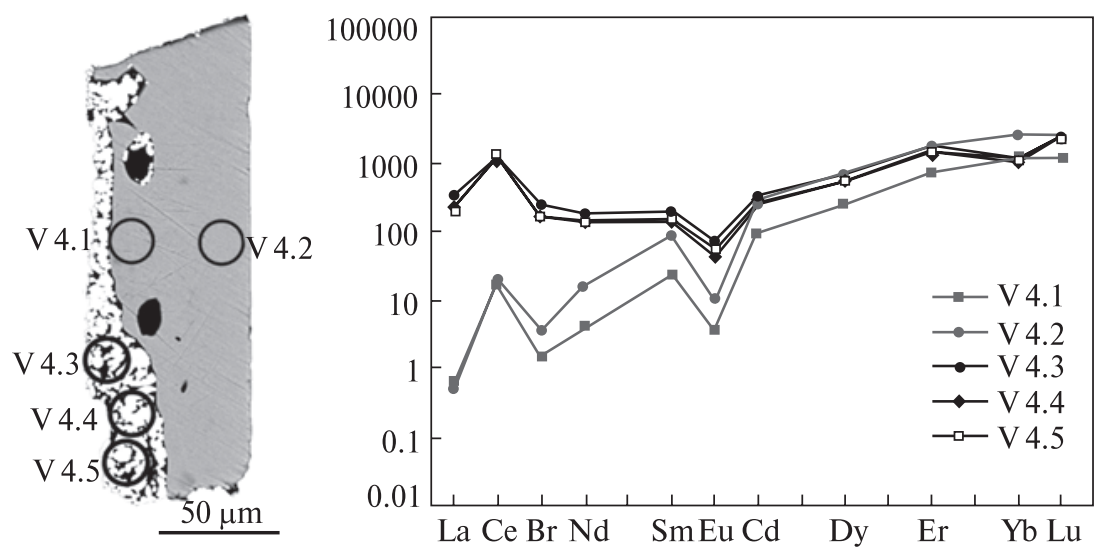

Inclusions were commonly hardened at 1100 , 1200 and $1300{ }^{\circ} \mathrm{C}$. The time taken for heating the inclusions to a hardening temperature varies from 6 to 20 hours, and maximum temperature exposure was maintained from 1 to 4 hours. A gas vesicle in inclusions in glass becomes noticeable at 650$750{ }^{\circ} \mathrm{C}$. The temperature at which a gas vesicle in silicate melt disappears is $1300{ }^{\circ} \mathrm{C}$. After the disappearance of the gas vesicle numerous globular and drop-like magnetite microaggregates with titanium impurity ( 0.16 to $2.69 \mathrm{wt} . \%$ ) persisted as an insoluble phase in many inclusions. Thus, the homogenization temperature of inclusions (and zircon crystallization) is slightly over $1300{ }^{\circ} \mathrm{C}$. A magnetite phase is crystallized at about $1100^{\circ} \mathrm{C}$ upon cooling of melt inclusions. Heterogeneous trap inclusions (after G.G. Lämmlein, protoheterogeneous inclusions) are occasionally encountered. The inclusion conserved a quartz phase, which occurs in zircon as protoheterogeneous inclusions. The glass is brownish-red in sealed inclusions and colourless in exposed inclusions.

Before hardening the melt inclusions consist of quartz, albite, K-feldspar and annite (Table 3, analysis no. 14). As a result of annite melting, nontransparent melt inclusions become transparent.

The chemical composition of primary melt inclusions in zircon was analyzed by electron probe analysis of glasses obtained by hardening the inclusions (Table 3).

Glasses in hardened primary melt inclusions in zircon crystals fall into two groups based on chemical composition (Table 3). They are consistent with two types of silicate magmatic melts (types of inclusions) formed upon liquation magma layering. Type I contains a high $\mathrm{SiO}_{2}$ concentration (leucosyenite composition), and type II contains elevated $\mathrm{FeO}$ and lower $\mathrm{SiO}_{2}$ concentrations

Table 3. Chemical composition (wt.\%) of glasses from hardened primary melt inclusions and annite inclusion (No. 14) in a primary melt inclusion in zircon from Velyka Vyska leucosyenite, as shown by electron probe analysis

\begin{tabular}{|l|c|c|c|c|c|c|c|c|c|c|c|c|c|c|}
\hline \multicolumn{1}{|c|}{ No. } & $1 / 3$ & 2 & 3 & 4 & 5 & $6 / 2$ & $7 / 5$ & $8 / 6$ & $9 / 3$ & $10 / 3$ & $11 / 3$ & 12 & $13 / 3$ & $14 / 3$ \\
\hline $\mathrm{SiO}_{2}$ & 70.91 & 66.80 & 69.28 & 67.31 & 49.98 & 46.95 & 69.94 & 73.38 & 54.66 & 71.36 & 74.06 & 69.11 & 67.46 & 41.12 \\
$\mathrm{TiO}_{2}$ & 0.21 & 0.31 & 0.31 & 0.11 & 0.50 & 0 & 0 & 0 & 0 & 0.27 & 0.02 & 0 & 0.28 & 0.67 \\
$\mathrm{Al}_{2} \mathrm{O}_{3}$ & 13.36 & 12.79 & 13.09 & 12.43 & 0.66 & 5.48 & 13.70 & 12.73 & 8.29 & 14.45 & 12.57 & 11.50 & 12.02 & 13.73 \\
$\mathrm{FeO}$ & 6.56 & 7.39 & 6.62 & 7.47 & 22.71 & 2.16 & 6.13 & 5.05 & 3.53 & 5.14 & 5.46 & 7.48 & 6.88 & 35.36 \\
$\mathrm{MnO}$ & 0 & 0 & 0 & 0 & 0.51 & 0 & 0 & 0 & 0 & 0 & 0 & 0 & 0 & 0.05 \\
$\mathrm{MgO}$ & 0.71 & 0.49 & 0.18 & 0.18 & 0.17 & 0 & 0.17 & 0 & 0.23 & 0.17 & 0.43 & 1.21 & 0.10 & 0.00 \\
$\mathrm{CaO}$ & 1.95 & 1.28 & 1.38 & 2.18 & 16.73 & 0.30 & 1.47 & 1.34 & 1.29 & 1.53 & 0.59 & 0.28 & 4.39 & 0.07 \\
$\mathrm{Na} \mathrm{O}_{2}$ & 1.96 & 2.06 & 1.31 & 1.78 & 1.47 & 2.03 & 2.89 & 2.55 & 0.91 & 2.29 & 2.69 & 1.89 & 1.68 & 0.27 \\
$\mathrm{~K}_{2} \mathrm{O}$ & 3.13 & 5.57 & 5.48 & 4.62 & 0.04 & 1.76 & 5.10 & 3.88 & 0.78 & 3.70 & 3.42 & 5.47 & 3.92 & 8.71 \\
$\mathrm{Cl}$ & $\mathrm{N} . \mathrm{d}$. & 0.23 & 0.06 & 0 & 0 & $\mathrm{~N} . \mathrm{d}$. & $\mathrm{N} . \mathrm{d}$. & $\mathrm{B} . \mathrm{d}$. & $\mathrm{N} . \mathrm{d}$. & $\mathrm{N} . \mathrm{d}$. & $\mathrm{N} . \mathrm{d}$. & 0.12 & $\mathrm{~N} . \mathrm{d}$. & $\mathrm{N} . \mathrm{d}$. \\
$\mathrm{ZrO}_{2}$ & 1.22 & 3.08 & 2.29 & 3.93 & 7.23 & 41.32 & 0.60 & 1.07 & 30.31 & 1.08 & 0.76 & 2.93 & 3.27 & 0 \\
$\mathrm{Total}$ & 100 & 100. & 100 & 100 & 100 & 100 & 100 & 100 & 100 & 100 & 100 & 100 & 100 & 99.62 \\
$T_{\text {hard }}{ }^{\circ} \mathrm{C}$ & 1300 & 1245 & 1245 & 1245 & 1245 & 1300 & 1300 & 1250 & 1250 & 1300 & 1300 & 1245 & 1300 & \\
\hline
\end{tabular}

$\mathrm{N}$ o t e. N. d. - no analysis done. $1 / \mathrm{n}-$ No of inclusion / number of analyzes. Microprobe analyzer: JSM 6700F with JED-2300 (analyzes No. 1, 6-11, 13, 14) and JSM-6510LA with EDS JED-2200 (analyzes No. 2-5, 12). 

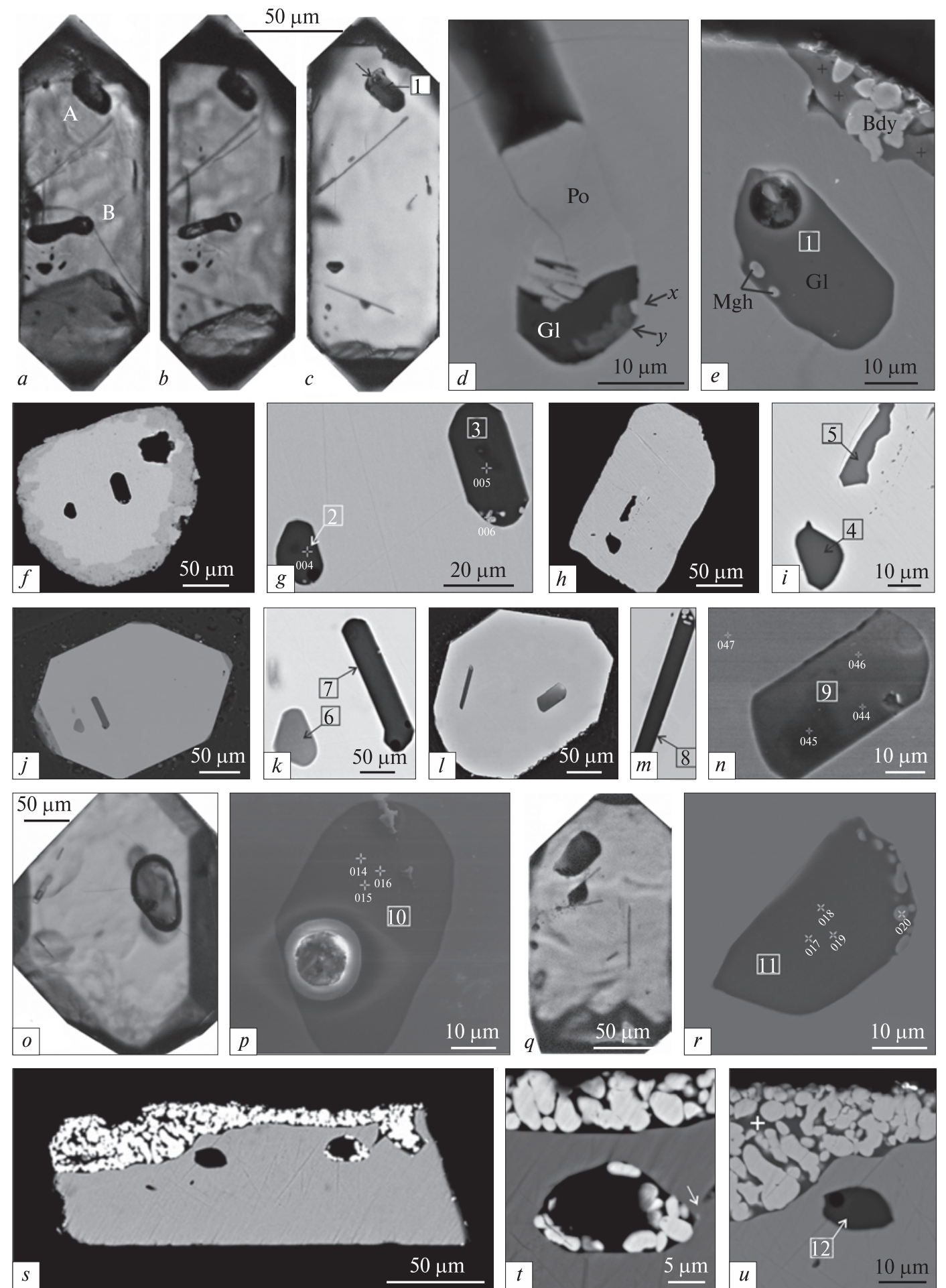

Fig. 5. Hardened primary melt inclusions in zircon from Velyka Vyska leucosyenite. $a-e-$ silicate inclusions of glass (A) and heterogeneous trapping of sulfide and silicate melts (B). $a, b, c-$ original view of a crystal (a) and inclusions B (b) and A $(c)$ prepared for electron probe analysis. The left portion of inclusion B is transparent $(b)$, because part of sulfide (pyrrhotite $\mathrm{Fe}_{0.86} \mathrm{~S}$ ) was lost while preparing the crystal for analysis. In the crystal of zircon ( $a, b, c$ images) is visible acicular apatite. $d, e-$ view of inclusions B and A, respectively, in the BSE mode. The arrow indicates a trace of a gas vesicle in silicate glass (c). The individual inclusions shown on images $g, i, k, m, n, p, r$ are from crystals $f, h, j, l, o, q$, respectively. ( $s$ ) - zircon V4 with baddeleyite individuals on the crystal prism facet. Baddeleyite aggregates in a melt inclusion $(t, u)$ with an analytical point subjected to electron probe analysis of glass (small cross). Primary melt inclusion no. $12(u)$. The melt inclusion with baddeleyite aggregates $(t)$ must have been overfilled. The arrow $(t)$ indicates the position of the fracture which connects the inclusion with a crystal surface zone with abundant baddeleyite. $a, b, c, j, l, o, q$ - photos from optical microscope, transmitted light, other photos are the BSE image. Po - pyrrhotite, $B d y$ - baddeleyite, $G l$ - silicate glass, $M g h-$ magnetite; $x$, $y-$ unidentified minerals. Inclusions $1-12$ correspond to numbers in Table 3 
(melanosyenite composition). Inclusions of type I in zircon crystals are most abundant. Primary inclusions of both types were revealed only in three zircon crystals (Fig. 5, Table 3, inclusions 4-5; 6-7; 8-9). The chemical composition of the inclusion phase (Fig. 5, $d$ ) (a JSM 6700F microanalyzer with JED-2300) suggests that sulfide melt, similar in composition to pyrrhotite $\left(\mathrm{Fe}_{0.86} \mathrm{~S}\right)$, was also involved in the formation of the massif.

$\mathrm{ZrO}_{2}$ concentration in glasses from hardened primary melt inclusions varies markedly but increases with a decrease in $\mathrm{SiO}_{2}$ concentration (Fig. 6). Two zones are shown on the diagram: a zone of leucosyenite composition is on the right and a zone of melanosyenite composition is on the left. $\mathrm{ZrO}_{2}$ concentration in glasses of leucosyenite composition varies from 0.60 to $3.93 \mathrm{wt} . \%$ and that of "melanosyenitic" glasses are 7.23 to 30.31 and 41.32 wt.\% (Fig. 5, Table 3, inclusions no. 5, 6 and 9). As the hardening temperature $\left(1250^{\circ} \mathrm{C}\right)$ of melt inclusion no. 9 is lower than the conservation temperature of the inclusion, the filling of the inclusion remained heterogeneous: a gas vesicle phase is transparent in the upper right corner; $\mathrm{ZrO}_{2}$ concentration varies from one point to another $(19.14 ; 27.79 ; 43.99$ wt.\%). A mean value is shown in Table 3.

$R E E$ minerals, such as monazite, parisite, bastnaesite, allanite and others occur in Velyka Vyska zircon [17, 19]. Therefore, the magmatic melt, from which zircon was crystallized, contained rareearth elements.

Discussion. The liquation layering of the magmatic melt is controlled by many factors and has not been thoroughly studied yet [26]. The contribution of magmatic melt to the formation of the deposits is indicated by the results of analyses of the melt inclusions.

The growth of zircon crystals from Velyka Vyska leucosyenite upon the layering of the magmatic melt is indicated by: (a) the presence of primary melt inclusions of leucosyenite (dominate in crystals) and melanosyenite melts; (b) the distribution of the figurative points of the glass compositions of primary melt inclusions in Velyka Vyska and Azov zircons [4, 19] on Greig pseudo ternary diagram (Fig. 7). These points lie between a low-temperature immiscibility zone in the leucite-fayalite-silica system (superposed by the compositions of coexisting glasses from lunar basalts not shown on the diagram) and a zone contains data on most of the volcanic rocks known on the earth showing the immiscibility of the melts.

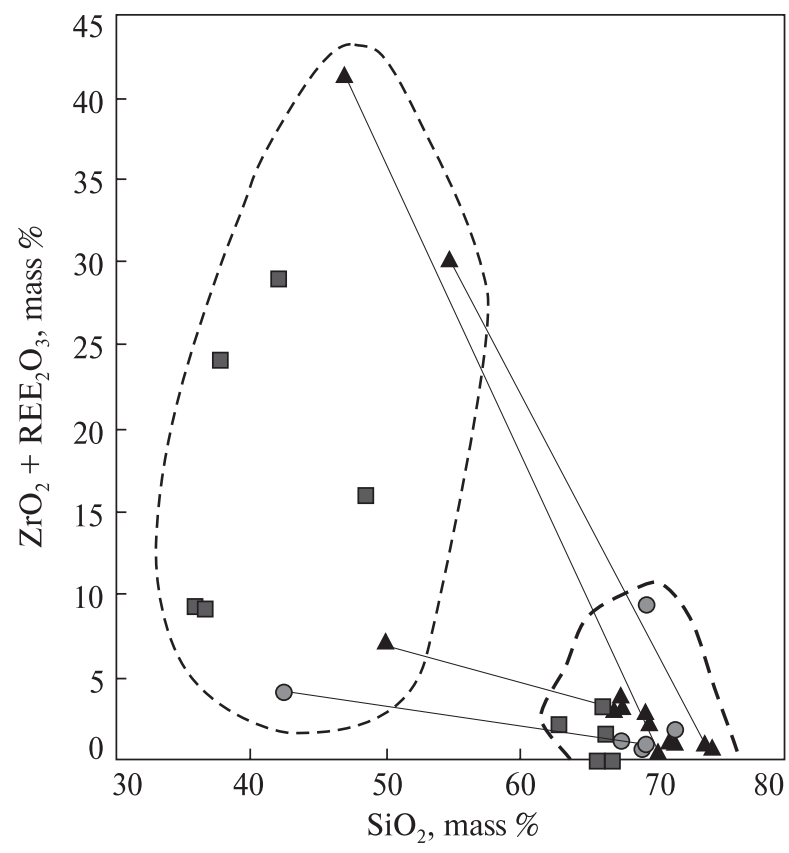

Fig. 6. Dependence of $\left(\mathrm{ZrO}_{2}+R E E_{2} \mathrm{O}_{3}\right)$ mass.\% on the $\mathrm{SiO}_{2}$ content of glass in experimentally hardened melt inclusions in zircon from the Azov $\mathrm{Zr}-R E E$ deposit (circles [4], and squares [19]) and the Velyka Vyska syenite massif (triangles)

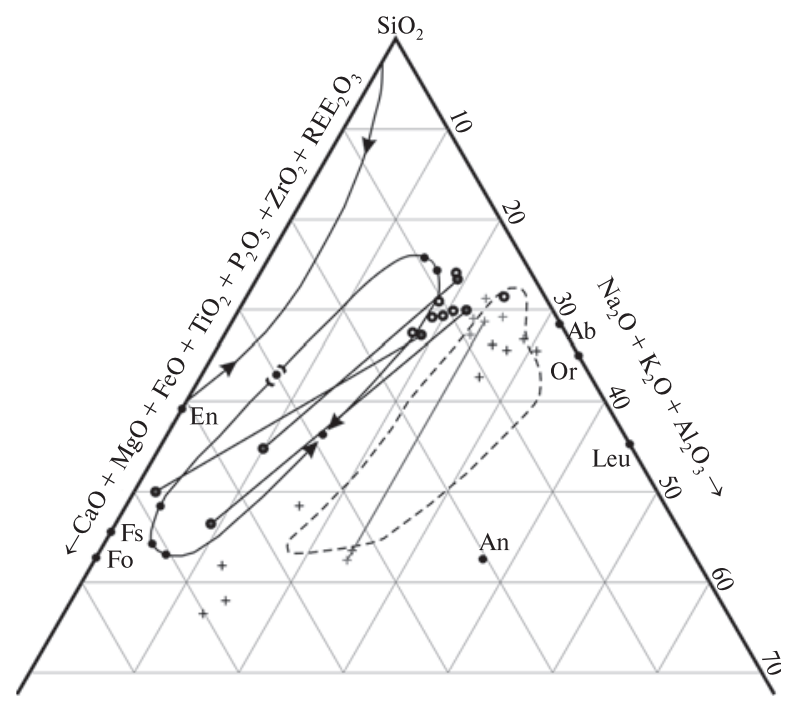

Fig. 7. Greig pseudo ternary diagram with some changes and additions. It shows a low-temperature immiscibility zone in the leucite-fayalite-silica system. A dashed line delineates a zone containing data on most volcanic rocks known on the earth which indicate the immiscibility of the melts [27]. Black circles indicate the compositions of melt inclusion glass in zircon from Velyka Vyska leucosyenites. Crosses indicate the compositions of glasses from melt inclusions in zircon from the ore zone of the Azov $\mathrm{Zr}-R E E$ deposit [4, 19]. All compositions were recalculated only for the oxides shown in the diagram. Connecting lines combine pairs of glass compositions for primary melt inclusions of two types in zircon crystals 
Table 4. Chemical composition (wt.\%) of glass, which contains baddeleyite microinclusions on zircon crystals from the Velyka Vyska syenite massif and the Azov $\mathrm{Zr}-R E E$ deposit

\begin{tabular}{|l|c|c|c|c|c|c|c|}
\hline \multicolumn{1}{|c|}{ Components } & \multicolumn{3}{|c|}{ The Velyka Vyska syenite massif } & \multicolumn{3}{c|}{ The Azov Zr-REE deposit [38] } \\
\hline $\mathrm{SiO}_{2}$ & 41.84 & 46.96 & 47.26 & 45.38 & 46.03 & 43.24 & 44.27 \\
$\mathrm{ZrO}_{2}$ & 23.26 & 6.52 & 8.72 & 8.54 & 2.95 & 3.04 & 3.13 \\
$\mathrm{HfO}_{2}$ & N.d. & N.d. & N.d. & N. d. & 0.00 & 0.04 & 0.08 \\
$\mathrm{TiO}_{2}$ & 0.08 & N.d. & N.d. & N. d.. & N. d. & N. d. & N. d. \\
$\mathrm{Al}_{2} \mathrm{O}_{3}$ & 4.23 & 1.19 & 1.36 & 1.26 & 24.78 & 27.00 & 26.47 \\
$\mathrm{FeO}$ & 4.90 & 11.36 & 9.79 & 11.92 & 4.23 & 4.02 & 4.73 \\
$\mathrm{MgO}$ & 1.56 & 0.87 & 0.95 & 0.92 & 0.48 & 0.53 & 0.52 \\
$\mathrm{CaO}$ & 24.12 & 33.10 & 31.92 & 31.98 & 9.16 & 11.11 & 9.85 \\
$\mathrm{Na}_{2} \mathrm{O}$ & N.d. & N.d. & N.d. & N.d. & 1.72 & 1.51 & 1.71 \\
$\mathrm{Y}_{2} \mathrm{O}_{3}$ & N.d. & N.d. & N.d. & N.d. & 1.25 & 0.87 & 0.56 \\
$\Sigma R E E$ oxides & N.d. & N.d. & N.d. & N.d. & 3.39 & 1.74 & 1.54 \\
$\mathrm{Ta}_{2} \mathrm{O}_{5}$ & N.d. & N.d. & N.d. & N.d. & 0.00 & 0.00 & 0.26 \\
$\mathrm{P}_{2} \mathrm{O}_{5}$ & N.d. & N.d. & N.d. & N.d. & 0.36 & 1.37 & 1.70 \\
Total & 99.99 & 100 & 100 & 100 & 94.35 & 94.47 & 94.81 \\
\hline
\end{tabular}

N o t e. N. d. - no analysis done. Microprobe analyzer: JSM 6700F with JED-2300 and JSM-6510LA with JED-2200.

The liquation layering of the magmatic melt was slow because the liquation melts are similar in density; leucosyenite melt, which is more abundant than melt of melanosyenite composition, displays a great dynamic viscosity; embryos of melt of melanosyenite composition are initially microscopic. The microglobules of melanosyenite composition in a leucosyenitic matrix that formed upon hardening of inclusion in Azov zircon are 2-3 $\mu \mathrm{m}$ in size [1].

The genesis of baddeleyite on zircon deserves special attention. The replacement of zircon by baddeleyite is scarce in contrast to the reverse situation. This is due to substantial differences in the conditions of their formation. For example, baddeleyite was revealed in Libyan Desert sand upon thermal zircon decay $\left(>1676^{\circ} \mathrm{C}\right)$ caused by lightning [5] and in the products of an impact crater formed by a meteorite [6]. If these extreme cases of baddeleyite's genesis are ruled out, then it means that it forms only when the crystallization medium is undersaturated with silica. It has been shown experimentally [36] that baddeleyite can form after zircon in silica-saturated rocks if a high-temperature fluid oversaturated with $\mathrm{Ca}$ (molar quantity of $\mathrm{Ca}$ is close to or greater than that of $\mathrm{Si}$ in the system) is involved. In this case, $\mathrm{Si}$ forms $\mathrm{CaSiO}_{3}$, thus making silica less active.

There are cases of the replacement of the zircon rim by baddeleyite in kimberlites subjected to mantle metasomatism [32]; the formation of baddeleyite after zircon due to desilication upon the rodingitization of garnet pyroxenites and granatites [18]; the transformation of the zircon rim into oriented baddeleyite intergrowths from the Ichetyu raremetal ore occurrence under the influence of hightemperature alkaline fluids [29].

In the Azov $\mathrm{Zr}$-REE deposit, baddeleyite was formed when zircon was affected by silicate melt with a low $\mathrm{SiO}_{2}$ concentration (Table 4) at PTparameters exceeding zircon crystallization conditions [38]. Their high values are caused by highpressure $\mathrm{CO}_{2}$-fluid flows, whose maximum PTparameter values exceeded zircon crystallization conditions. They provoked the explosion of primary melt inclusions, forming glass inclusions in zircon crystals from the ore zone of the Azov $\mathrm{Zr}-R E E$ deposit. Fluid flow pressure was reconstructed from the secondary inclusions of the homogeneous and heterogeneous trapping of glass and liquid $\mathrm{CO}_{2}$-fluid. At $1200{ }^{\circ} \mathrm{C}$ it was 450 $520 \mathrm{MPa}[38,39]$.

Baddeleyite was crystallized on the zircon surface and inside the inclusions. $\mathrm{CO}_{2}$-fluid flows penetrated the rock along a system of microfractures produced by deep tectonic dislocations. They occur locally, accounting for rare finds of unusual baddeleyite aggregates.

Baddeleyite in Velyka Vyska leucosyenites was found on two zircon crystals (Figs. 2 and $5, e$ ). It is similar in shape, size and relation to zircon to baddeleyite from the Azov deposit. It is assumed to have been formed in the same way. $\mathrm{As}_{\mathrm{SiO}_{2}}$, which formed upon zircon decomposition $\left(\mathrm{Zr}\left[\mathrm{SiO}_{4}\right] \rightarrow\right.$ $\rightarrow \mathrm{ZrO}_{2}+\mathrm{SiO}_{2}$ ), became part of silicate melt, $\mathrm{SiO}_{2}$ ISSN 2519-2396. Mineral. Journ. (Ukraine). 2021. 43, No. 1 
concentration in its initial composition could have been lower than that of glass containing baddeleyite aggregates (Table 4). The glass contains high $\mathrm{CaO}$ and low $\mathrm{SiO}_{2}$ concentrations, for example the medium constituents affecting the replacement of zircon by baddeleyite. The $\mathrm{ZrO}_{2}$ concentration estimated in the glass is elevated under the influence of baddeleyite, whose individuals are close to each other. It seems to be similar to its concentration in glass from the Azov $\mathrm{Zr}-R E E$ deposit. Thus, it is assumed that the partial replacement of zircon by baddeleyite upon the formation of the Velyka Vyska syenite massif was also contributed by high-pressure $\mathrm{CO}_{2}$-fluid flows.

Conclusions. 1. Leucosyenitic melt was crystallized in the liquation layering medium of magmatic melt, which was involved in the formation of the Velyka Vyska syenite massif. This conclusion is based on: (a) many finds of primary melt inclusions of leucosyenite composition and sometimes primary melt inclusions of melanosyenite composition in zircon crystals; (b) the distribution of the figurative composition points of two types of glasses from hardened melt inclusions in zircon crystals on Greig pseudo ternary diagram. The conservation temperature of melt inclusions in zircon crystals from Velyka Vyska leucosyenite is slightly over $1300{ }^{\circ} \mathrm{C}$, but titanium concentrations in zircon (Tiin-Zrn thermometer) show that it is much lower (800-1000 $\left.{ }^{\circ} \mathrm{C}\right)$.

2. Zircon also hosts primary inclusions that trapped sulfide (pyrrhotite $\mathrm{Fe}_{0.86} \mathrm{~S}$ ) melt, which seems to have formed when $\mathrm{H}_{2} \mathrm{~S}$ flows penetrated the mineral-forming medium of ferruginous syenite melt. They did not occur often.

3. The bulk of the substance that makes up Velyka Vyska zircon crystals displays $R E E$ distribution spectra characteristic of zircon of magmatic genesis, and the dark rim on the crystal edge (in the BSE image) is typical of zircon from a rock strongly affected by high-pressure $\mathrm{CO}_{2}$-fluid flow. Also associated with them is the formation of baddeleyite microinclusions in the glass upon zircon replacement. The high PT-parameters of $\mathrm{CO}_{2}$-fluid, obtained for the Azov $\mathrm{Zr}-R E E$ deposit, suggest that it was supplied to the deposit from deep mantle layers along deep tectonic dislocations.

4. The conditions of formation of the Velyka Vyska syenite massif and the Azov $\mathrm{Zr}-R E E$ deposit have the following common features: (a) magmatic melt liquation; (b) high $\mathrm{ZrO}_{2}$ concentrations in glass from hardened primary melt inclusions in zircon crystals (and in magmatic melt); (c) the supply of high-pressure $\mathrm{CO}_{2}$-fluid flows. The similar conditions of formation of the massifs suggest the occurrence of high-grade $\mathrm{Zr}$ ores and $R E E$ in the Velyka Vyska syenite massif. This information complements the existing assessment of the ore prospects of the Velyka Vyska syenite massif.

Acknowledgements. The authors wish to thank O.L. Galankina (IPGG RAS), S.G. Simakin and E.V. Potapov (Valiev IPT RAS, Yaroslavl Branch) for their assistance in zircon studies. The study was conducted under IPGG RAS Research Project FMNU-2019-0002.

\section{REFERENCES}

1. Sheremet, E.M., Melnikov, V.S., Strekozov, S.N., Kozar, N.A. and Voznyak, D.K. (2012), Azovskoe redkozemel'noe mestorozhdenie Priazovskogo megabloka Ukrainskogo shchita (geologiya, mineralogiya, geokhimiya, genezis, rudy, kompleksnye kriterii poiskov, problemy ekspluatatsii), in Ponomarenko, A.N. and Antsiferov, A.V. (eds), Noulidzh, Donetsk, UA, 374 p. [in Russian].

2. Voznyak, D.K. (2007), Micro-inclusion and reconstruction of conditions of endogenous mineral formation, Nauk. dumka, Kyiv, 280 p. [in Ukrainian].

3. Voznyak, D. and Kvasnytsya, V. (2010), Geologist Ukraine, No. 1-2, Kyiv, UA, pp. 48-61 [in Ukrainian].

4. Voznyak, D.K., Sobolev, V.B., Kulchytska, H.O., Belskyi, V.M. and Galaburda, Yu.A. (2012), Dopov. Nac. akad. nauk $U k r$., No. 3, Kyiv, UA, pp. 110-117 [in Ukrainian].

5. Godovikov, A.A. (1983), Mineralogy, Nedra, Moscow, RU, 647 p. [in Russian].

6. Gurov, Ye.P. and Permyakov, V.V. (2016), Mineral. Journ. (Ukraine), Vol. 38, No. 1, Kyiv, pp. 12-20 [in Russian]. https:// doi.org/10.15407/mineraljournal.38.01.012

7. Dubyna, O.V. and Kryvdik, S.G. (2013), Mineral. Journ. (Ukraine), Vol. 35, No. 3, Kyiv, pp. 61-72 [in Ukrainian].

8. Kalyuzhnyi, V.A. (1960), Methods for studying multiphase inclusions in minerals, Vyd-vo AN UkrRSR, Kyiv, UA, 168 p. [in Ukrainian].

9. Kalyuzhnyi, V.A. (1982), Fundamentals of the doctrine of mineral-forming fluids, Nauk. dumka, Kyiv, UA, 239 p. [in Russian].

10. Kvasnytsya, V.M., Vyshnevskyi, O.A., Kvasnytsya, I.V. and Hurnenko, I.V. (2016), Mineral. Journ. (Ukraine), Vol. 38, No. 3, Kyiv, pp. 9-23 [in Ukrainian]. https://doi.org/10.15407/mineraljournal.38.03.009

11. Kryvdik, S.G. (2002), Geochem. Int., No. 7, RU, pp. 707-717 [in Russian].

12. Kryvdik, S.G. and Bezsmolova, I.V. (2011), Geol.journ., No. 3, Kyiv, UA, pp. 39-45 [in Ukrainian]. 
13. Kryvdik, S.G., Zagnitko, V.N., Strekozov, S.N., Gursky, D.S., Vasilchenko, V.V. and Matviychuk, M.V. (2000), Mineral. Journ. (Ukraine), Vol. 22, No. 1, Kyiv, pp. 62-72 [in Ukrainian].

14. Kryvdik, S.G., Orsa, V.I. and Bryanskiy, V.P. (1988), Geol.journ., No. 6, Kyiv, pp. 43-53 [in Russian].

15. Kryvdik, S.G. and Tkachuk, V.I. (1990), Petrology of alkaline rocks of the Ukrainian Shield, Nauk. dumka, Kyiv, 408 p. [in Russian].

16. Krochuk, V.M., Legkova, G.V., Galaburda, Yu.A., Orsa, V.I. and Usova, L.V. (1989), Mineral. Journ. (Ukraine), Vol. 11, No. 6, Kyiv, pp. 18-29 [in Russian].

17. Kulchytska, H.O., Herasimets, I.M., Vyshnevskyi, O.A. and Belskyi, V.M. (2019), Mineral. Journ. (Ukraine), Vol. 41, No. 2, Kyiv, pp. 34-44 [in Ukrainian]. https://doi.org/10.15407/mineraljournal.41.02.034

18. Kuznetsov, D.V. and Mukatova, A. (2013), Trudy Inst. geol. i geohimii im. A.N. Zavaritskogo, No. 160, RU, pp. 224-228 [in Russian].

19. Levashova, E.V., Voznyak, D.K., Skublov, S.G., Kaulina, T.V., Kulchytska, H.O. and Galankina, O.L. (2019), Mineral. Journ. (Ukraine), Vol. 41, No. 2, Kyiv, UA, pp. 45-61 [in Russian]. https://doi.org/10.15407/mineraljournal.41.02.045

20. Lemmlein, G.G. (1959), Zap. Vsesoyuz. mineral. ob-va, Vol. 88, No. 2, Moscow, RU, pp. 137-143 [in Russian].

21. Melnykov, V.S. (2004), Materialy nauk.-tekh. narady, Kyiv, April 27-29, UA, pp. 148-150 [in Ukrainian].

22. Melnykov, V.S. (2005), Sci. proc. UkrSGRI, No. 1, Kyiv, UA, pp. 92-100 [in Ukrainian].

23. Melnikov, V.S., Voznyak, D.K., Grechanovskaya, E.E., Gursky, D.S., Kulchytska, H.O. and Strekozov, S.N. (2000), Mineral. Journ. (Ukraine), Vol. 22, No. 1, Kyiv, UA, pp. 42-61 [in Russian].

24. Melnikov, V.S., Kulchytska, H.O., Kryvdik, S.G. and Strekozov, S.M. (2001), Mineral. Journ. (Ukraine), Vol. 23, No. 4, Kyiv, UA, pp. 19-33 [in Ukrainian].

25. Mokievskyi, V.A. and Yang, Feng-Chun (1961), Notes Russian Mineral. Soc., Ch. 90, Iss. 5, RU, pp. $510-520$ [in Russian].

26. Redder, E. (1979), Silicate liquid immiscibility in magmas. The Evolution of the igneous rocks: fiftieth anniversary perspectives, in Yoder, H.S. (ed.), Princeton Univ. Press, Princeton, Guildford, pp. 15-57.

27. Redder, E. (1987), Fluid inclusions in minerals, in 2 vol., Vol. 1, 558 p.; Vol. 2, Mir, Moscow, 632 p. [in Russian].

28. Skublov, S.G. (2005), Geochemistry of rare earth elements in rock-forming metamorphic minerals, Nauka, St. Petersburg, RU, 147 p. [in Russian].

29. Skublov, S.G., Krasotkina, A.O., Makeev, A.B., Galankina, O.L. and Melnik, A.E. (2018), Geologiya i razvedka, No. 1, RU, pp. 27-35. https://doi.org/10.32454/0016-7762-2018-1-27-35

30. Fedotova, A.A., Bibikova, E.V. and Simakin, S.G. (2008), Geochemistry, No. 9, RU, pp. $980-997$ [in Russian]. https:// doi.org/10.1134/S001670290809005X

31. Harley, S.L. and Kelly, N.M. (2007), Elements, Vol. 3, No. 1, pp. 13-18. https://doi.org/10.2113/gselements.3.1.13

32. Heaman, L.M., LeCheminant, A.N. (1993), Chem. Geol., Vol. 110, No. 1-3, pp. 95-126.

33. Hinton, R.W. and Upton, B.G.J. (1991), Geochim. et Cosmochim. Acta, Vol. 55, Iss. 11, pp. 3287-3302. https://doi. org/10.1016/0016-7037(91)90489-R

34. Hoskin, P.W.O. and Schaltegger, U. (2003), Review Mineral. and Geochem., Vol. 53, No. 1, pp. 27-62. https://doi. org/10.2113/0530027

35. Levashova, E.V., Kulchytska, H.O., Skublov, S.G., Herasymets, I.M., Kryvdik, S.G., Galankina, O.L., Mamykina, M.E. and Levashov, D.S. (2020), Mineral. Journ. (Ukraine), Vol. 42, No. 3, Kyiv, UA, pp. 39-49 [in English]. https://doi. org/10.15407/mineraljournal.42.03.039

36. Lewerentz, A., Harlov, D.E., Scherstén, A. and Whitehouse, M.J. (2019), Contribs. Mineral. and Petrol., Vol. 174, No. 8, p. 64. https://doi.org/10.1007/s00410-019-1600-8

37. McDonough, W.F. and Sun, S.-S. (1995), Chem. Geol., 120, Iss. 3-4, pp. 223-253. https://doi.org/10.1016/0009-2541(94)00140-4

38. Voznyak, D.K., Chernysh, D.S., Melnikov, V.S. and Ostapenko, S.S. (2013), Mineralogia, Vol. 44, Iss. 3-4, Warsaw, PL, pp. 125-131. https://doi.org/10.2478/mipo-2013-0009

39. Voznyak, D.K., Melnikov, V.S., Chernysh, D.S. and Ostapenko, S.S. (2010), Biennial Conf. of Asian Current Research on Fluid Inclusions (ACROFI III) and 14 ${ }^{\text {th }}$ Intern. Conf. on Termobarogeochemistry (TBG XIV), Novosibirsk, 15-20 Sept., 2010, VS Sobolev Inst. of Geology and Mineralogy, Publ. House of SB RAS, Novosibirsk, RU, pp. 260-261.

40. Watson, E.B., Wark, D.A. and Thomas, J.B. (2006), Contribs. Mineral. and Petrol., Vol. 151, pp. 413-433. https://doi. org/10.1007/s00410-006-0068-5

Received 02.10.2020 
Д.К. Возняк, д-р геол. наук, гол. наук. співроб.

Інститут геохімії, мінералогії та рудоутворення ім. М.П. Семененка НАН України

03142, м. Київ, Україна, пр. Акад. Палладіна, 34

E-mail: dkvoznyak@ukr.net; https://orcid.org/0000-0002-6124-2033

K.В. Лєвашова, канд. геол.-мін. наук, мол. наук, співроб.

Інститут геології та геохронології докембрію РАН

199034, м. Санкт-Петербург, РФ, наб. Макарова, 2

E-mail: levashova.kateryna@yandex.ru https://orcid.org/0000-0002-0814-1428

С.Г. Скублов, д-р геол.-мін. наук, проф., гол. наук. співроб.

Інститут геології та геохронології докембрію РАН

199034, м. Санкт-Петербург, РФ, наб. Макарова, 2

Санкт-Петербурзький гірничий університет

199106, м. Санкт-Петербург, РФ, ВО, 21 лінія, 2

E-mail: skublov@yandex.ru; http://orcid.org/0000-0002-5227-4260

С.Г. Кривдік, д-р геол.-мін. наук, проф., пров. наук. співроб.

Інститут геохімії, мінералогії та рудоутворення ім. М.П. Семененка НАН України

03142, м. Київ, Україна, пр. Акад. Палладіна, 34

E-mail: kryvdik@ukr.net; http://orcid.org/0000-0002-8356-1115

A.О. Вишневський, канд. геол.-мін. наук, пров. наук. співроб.

Інститут геохімії, мінералогії та рудоутворення ім. М.П. Семененка НАН України

03142, м. Київ, Україна, пр. Акад. Палладіна, 34

E-mail: vyshnevskyy@i.ua; ResearcherID: I-9996-2018

B.M. Бельський, канд. геол. наук, наук. співроб.

Інститут геохімії, мінералогії та рудоутворення ім. М.П. Семененка НАН України

03142, м. Київ, Україна, пр. Акад. Палладіна, 34

E-mail: belskyi_vm@ukr.net; https://orcid.org/0000-0001-7990-1386

C.I. Курило, канд. геол. наук, наук. співроб.

Інститут наук про Землю Словацька академія наук

974 01, Банська-Бистриця, Словаччина, Думбієрська, 1

E-mail: kurylo.sergiy@gmail.com; https://orcid.org/0000-0003-4466-6851

\section{ОСОБЛИВОСТІ ФОРМУВАННЯ ВЕЛИКОВИСКІВСЬКОГО \\ СІЕНІТОВОГО МАСИВУ (КОРСУНЬ-НОВОМИРГОРОДСЬКИЙ ПЛУТОН, УКРАЇНСЬКИЙ ЩИТ) ЗА РОЗПЛАВНИМИ ВКЛЮЧЕННЯМИ У ЦИРКОНІ}

Лейкосієніти Великовисківського сієнітового масиву формувалися в процесі лікваційного розшарування магматичного розплаву. Це твердження базується на наявності двох типів первинних розплавних включень різного хімічного складу в кристалах циркону з лейкосієнітів масиву. Вони відповідають двом типам силікатних розплавів. Перший тип - лейкосієнітовий, відзначається високою концентрацією $\mathrm{SiO}_{2}$ (включення кількісно домінують в цирконі); другий тип - меланосієнітовий, характеризується підвищеним вмістом заліза і меншим $\mathrm{SiO}_{2}$. Лікваційне розшарування магматичного розплаву відбувалося з невеликою швидкістю, оскільки: густини лікватів близькі; лейкосієнітовий розплав, обсяг якого переважає над розплавом меланосієнітового складу, відмінний більшою динамічною в'язкістю; початкові величини зародків меланосієнітового складу мають мікроскопічні розміри. Під час формування масиву існував, також, і сульфідний розплав, подібний за складом до піротину. Кристалізація циркону за температурами гомогенізації первинних розплавних включень відбувалася вище $1300{ }^{\circ} \mathrm{C}$, проте, за даними вмісту титану в цирконах ( $T$ Ti-Zrn) температура кристасталізації значно нижча $\left(800-1000{ }^{\circ} \mathrm{C}\right)$. Спектри розподілу $R E E$ основної речовини кристалів циркону Великовисківського масиву ідентичні до циркону Азовського і Яструбецького сієнітових масивів, з якими пов'язані родовища багатих руд $\mathrm{Zr}$ і $R E E$ (Азовське та Яструбецьке). Вони характерні для циркону магматичного генезису. У деяких зернах встановлено контрастні до основної маси кристала, темно-сірі в режимі $B S E$, облямівки, що характеризуються пологими спектрами розподілу $R E E$. Подібні спектри притаманні і баделеїту, що утворився внаслідок часткового заміщення кристалів циркону. Генезис темносірої облямівки циркону і баделеїту пов'язаний з інтенсивним впливом на породу високотермобаричного потоку $\mathrm{CO}_{2}$-флюїду. Особливості формування Великовисківського і Азовського масивів характеризуються загальними рисами: (а) ліквацією силікатного розплаву; (б) високим вмістом $\mathrm{ZrO}_{2}$ в стеклах загартованих первинних розплавних включень; (в) надходженням в тверду породу об'єктів високотермобаричних потоків $\mathrm{CO}_{2}$-флюїду. Подібні умови утворення дають змогу припускати на Великовисківському сієнітовому масиві знахідки багатих на $\mathrm{Zr}$ і $R E E$ руд.

Ключові слова: сієніт, розплавні включення, циркон, $R E E$, Великовисківський масив, Український щит. 